\title{
The Olenekian carbonates of the Bucovinian nappe (the central sector of the Hăghimaş syncline, Eastern Carpathians): lithology and microfacies
}

\section{Daniela Alexandra POPESCU* \& Liviu Gheorghe POPESCU}

„Ştefan cel Mare” University, Suceava, Faculty of History and Geography, Department of Geography, University Street 9, 720225, Suceava, Romania

Received 20 October 2004; accepted 16 August 2005

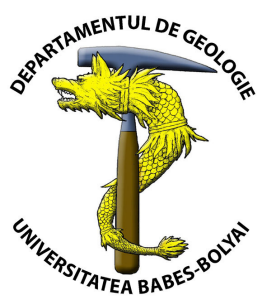

\begin{abstract}
Early Triassic carbonate outcrops were studied in the central sector of the Hăghimaş Syncline with regard to stratigraphy, microfacies and facies interpretation. This is the first microfacies study of these deposits. Early Triassic carbonates in the Hăghimaş Syncline are represented by two stratified successions: limestones and dolomites. The limestones overlie very rarely the detritic basal deposits (Induan) which marks the beginning of the alpine transgression. The stratified dolomites underlie frequently the Early Anisian massive dolomites. The contact between the stratified limestones and stratified dolomites is only exposed on Calu brook outcrop (the western flank of the Hăghimaş Syncline). The age of the investigated carbonates is Olenekian, based on the occurrence of Meandrospira pusilla biozone (in limestones). The foraminifera are very scarce in dolomites, represented mostly by Earlandia taxa. Microfacies data indicate the existence of a carbonate platform. The Olenekian carbonates yield a broad spectrum of microfacies types, predominantly micrites and biomicrites with foraminifera associated with echinoderms, ostracods, radiolarians, calcitized gastropods etc. These facies types are also known from the carbonate platforms in other parts of the Tethys.
\end{abstract}

Key words: Limestone, Dolomite, Microfacies, Olenekian (Early Triassic), Bucovinian Nappe, Hăghimaş Syncline.

\section{INTRODUCTION}

The Bucovinian Nappe occupies the largest surface of the Crystalline-Mesozoic Area and has a higher structural position compared to the lower units, the Infrabucovinian and the Subbucovinian Nappes. The Bucovinian Nappe supports the remains of a Mesozoic sedimentary series associated with ophiolites of Triassic-Middle Jurassic age but without crystalline basement, which is part of the Transylvanian Nappe (gravitational decollement nappes). All the nappes mentioned are part of the Outer Marginal Syncline. The syncline's name proposed by Uhlig (1907) derives from its position in respect to the central-Carpathian crystalline. The outcropping of the crystalline in the Bistriței Mountains region caused the fragmentation of the Outer Marginal Syncline into two distinct areas: to the north, the Rarău Syncline and to the south, the Hăghimaş Syncline.

As a thrust-sheet, the Bucovinian Nappe possesses a basement made up of a few metamorphic series which, according to their age and metamorphism degree, are: the Bretila, the Rebra and the Negrișoara meso-metamorphic series and the Tulgheş epimetamorphic series (Săndulescu, 1984). Besides these main series other lithologic units have been described, such as: the Chiril series (Nedelcu, 1982), the Dămuc series (Mureşan, 1967, 1976), the Mândra series (Balintoni et al., 1983; Vodă, 1980).

The Bucovinian sedimentary overlying the crystalline basement is characterized by the most complete succession of all the Central-Eastern Carpathian Nappes, starting with the Triassic and ending with the Barremian-Aptian wildflysch. The deposits of this succession are grouped into several sedimentary cycles separated by paraconformities and angular unconformities.

The Triassic sedimentary deposits of the Bucovinian Nappe outcrop on both flanks of the Outer Marginal Syncline but have a greater extent and a more complex composition on the inner (western) flank.

\section{LITHOLOGY AND STRATIGRAPHY}

The Triassic succession in the "Bucovinian facies" starts with the rudite-arenite Induan which corresponds to the first marine transgression of the Alpine cycle, continues with thick deposits of carbonate rocks representative of the neritic-littoral domain, and belong to the Olenekian-?Norian interval. In the outcrops that have been studied in the central sector of the Hăghimaş Syncline (Fig. 1), e.g., the outcrop situated at the confluence of the Calu brook and Piatra Roşie brook (Fig. 2) and the outcrop located on the eastern side of the Piatra Arşiţei Massif (Fig. 3), only Induan and Olenekian deposits have been found.

Induan. The rudite-arenite Induan succession is transgressively placed over the crystalline basement and has a variable thickness of 5 to $30 \mathrm{~m}$. Where the succession is complete, it is made up of conglomerates, micro- 
conglomerates and quartzitic sandstones which occasionally are associated with reddish clays. Such deposits are spread unevenly within the Outer Marginal Syncline. Among the Induan detritic deposits, the micro-conglomerates and sandstones are most frequent covering greater outcrop areas in the Rarău Syncline compared the Hăghimaş Syncline.

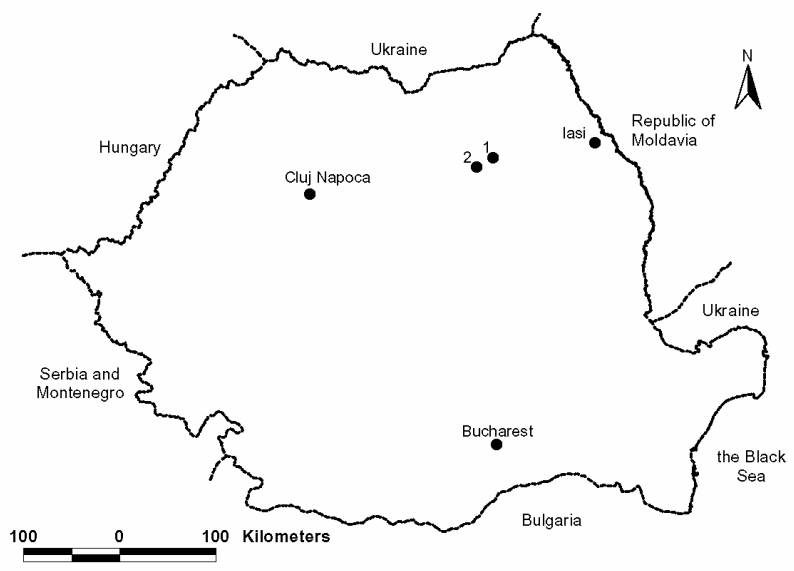

Fig. 1. Location of the Piatra Arşiței (1) and Calu (2) outcrops.

The lack of detritic Induan from the base of the Olenekian-Early Anisian deposits, largely represented by dolomites, from certain outcrops is explained by Săndulescu $(1968,1969,1975)$ by the existence of an erosion period caused by inter-Werfenian (Early Triassic) tectonic activity accompanied by the dolomite slow gravitational decollement from their crystalline basement.

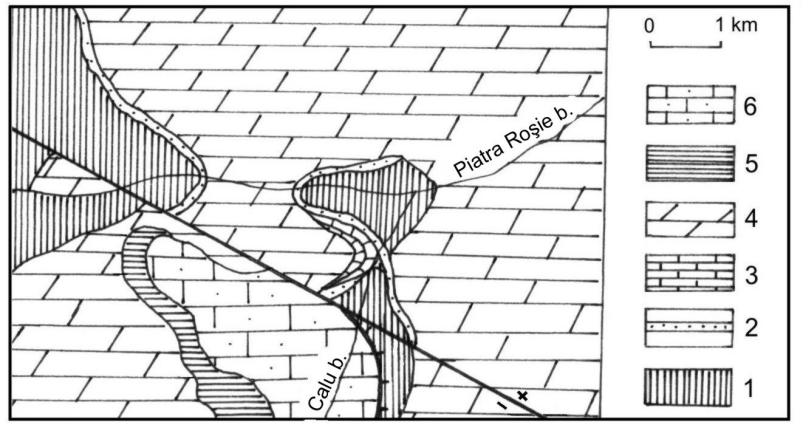

Fig. 2. Sketch map of the Calu brook-Piatra Arşiței brook confluence (the western flank of the Hăghimaş Syncline) according to Săndulescu et al., 1975): 1-crystalline basement;

2-conglomerates and sandstones (Induan); 3-carbonate stratified deposits (Olenekian); 4-massive dolomites (Early Anisian); 5-algal limestones (Middle Anisian-Ladinian);

6-terrigenous limestones (Middle Jurasic).

Olenekian. Over the detritic deposits and sometimes directly over the crystalline basement, both in Rarău and Hăghimaş Synclines, a stratified fossil bearing carbonate complex is present, made up of two distinct successions: limestones in the lower part, and dolomites in the upper part. Identifying both successions under the massive Anisian dolomites was possible only on few outcrops. Frequently only one of them crops out. The thickness of the entire complex varies from about 10 to $12 \mathrm{~m}$ north of Breaza, on the inner flank of the Rarău Syncline (Dimian, 1970), to almost $36 \mathrm{~m}$ in Piatra Cifronca Massif of the Hăghimaş Syncline (Grasu et al., 1995).

The lower succession is formed of grey limestones (white-yellowish on altered surfaces), either fine or coarse, arranged in beds of some centimeter thickness; they possess numerous white calcite joints. These limestones contain rarely mica sandstones intercalations. The stratified limestones are fossiliferous. Atanasiu (1928) described a faunal assemblage of Campilian (Olenekian) age at Azodu Mare.

Initially this succession was considered to be made up of dolomitic limestones (Atanasiu, 1928; Mutihac, 1968, 1969, 1990; Grasu, 1971; Patrulius 1966, 1967; Săndulescu, 1973) or marly limestones (Turculeț, 1967). Chemical analyses of samples colected from the fossiliferous deposits of Azodu Mare have proved the existence of certain limestones with quartz silt-sericite and sericite-quartz silt variations (Grasu et al., 1995).

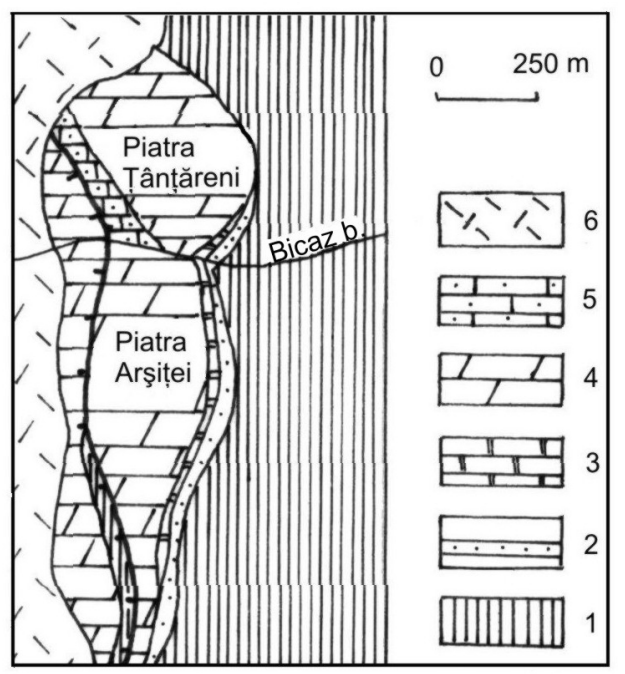

Fig. 3. Sketch map of the Piatra Arşiței Massif (the eastern flank of the Hăghimaş Syncline)(according to Săndulescu et al., 1975):

1-crystalline basement; 2- sandstones (Induan); 3-stratified dolomites (Olenekian); 4-massive dolomites (Early Anisian); 5-terrigenous limestones (Middle Jurasic); 6-wildflysch (Barremian-Aptian).

The stratified limestones have an uneven development in different sectors. They were better recognized in the whole Crystalline Mesozoic Area after the discovery of the Olenekian fauna at Azodu Mare. They have been identified for instance in the middle part of the Hăghimaş Syncline, at the Trotuş River springs (Băncilă, 1941). In the central part of the same syncline, on the inner flank, they appear in the south-eastern side of the dolomite massif from Piatra Ciofronca, overlying the Induan sandstones and underlying the stratified dolomites (Preda \& Pelin, 1963; Turculeț, 1967). The stratified limestones also occur to the confluence of the Piatra Roşie brook with Calu brook (Grasu, 1971; Grasu et al., 1995). In the Tulgheş area, Grasu (1971) found the same fossiliferous limestone succession under the massive dolomites from the Borvizului brook.

Similar limestones crop out intermittently in the Rarău Syncline, only on the inner flank of the syncline.

The upper succession of the Olenekian_is made up of dolomites and calcareous dolomites which are very different compared to the Early Anisian superjacent massive dolomites by their obvious stratification. This succession might be found more often under the Early Anisian dolomites than the limestone succession, but its fauna content is scarcer. Frequently, where the limestones are missing, the stratified dolomites laid directly over the detritic Induan deposits.

The clearly superposition of the stratified limestones and stratified dolomites is visible in the outcrop at the confluence between the Calu brook and Piatra Roşie brook 
as well as in Piatra Ciofronca Massif, on the inner flank of the Hăghimaş Syncline (Grasu, 1971; Grasu et al., 1995).

Early Anisian. The deposits which overlie the stratified limestones and stratified dolomites are made of massive dolomites, 50 to $100 \mathrm{~m}$ thick. In the Piatra Arşiţei outcrop, the massive dolomites are placed over the stratified dolomites which overlie directly the Induan detritic deposits.

\section{STUDIED OUTCROPS}

Detailed facies, sedimentological and palaeontological analysis of the carbonate Olenekian deposits were carried out of two outcrops: the first is situated at the confluence between Calu brook and Piatra Roșie brook and the other one on the western side of the Piatra Arşiței Massif. Quantitative microfacies analyses were carried out on thin sections.

\section{The stratified limestones}

These limestones have been systematically sampled on a single outcrop situated on the inner flank of the Hăghimaş Syncline, on Calu brook, at about $200 \mathrm{~m}$ up-stream from the Piatra Roşie brook confluence. In this outcrop, the carbonate complex follows over the Induan sandstones. The boundary between the sandstones and the stratified limestones, as well as the boundary between the stratified limestones and the overlying stratified dolomites is covered by deluvial material, making difficult to appreciate the thickness of these three rock successions (Fig. 4). The stratified limestones occur as two packs, each of $4 \mathrm{~m}$ thickness. They are fine grey limestones with brownish hues (the first pack, samples 86 to 96) and blue hues (the second pack, samples 97 to 99), intersected by white calcite joints. The main characteristic of these limestones is the evident stratification. They are stratified in thin beds of up to $3 \mathrm{~cm}$ thickness in the first pack and reaching 10 to $14 \mathrm{~cm}$ thickness in the second pack.

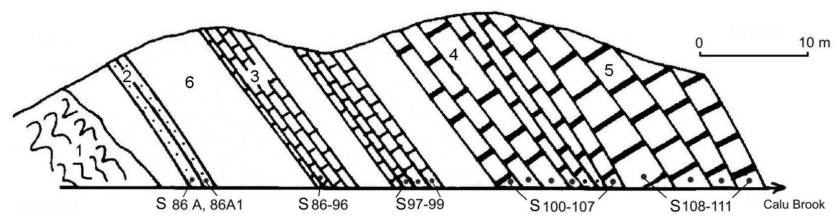

Fig. 4. Geological sketch of the Triassic deposits from the Calu outcrop (according to Grasu et al., 1995): 1-Bretila crystalline

Series; 2-sandstones (Induan); 3-stratified limestones and

4-stratified dolomites (Olenekian); 5-massive dolomites (Early Anisian); 6-covered interval; S-sample.

\section{The stratified dolomites}

The stratified dolomites have been sampled in the Hăghimaş Syncline on two outcrops: the Calu brook (samples 100 to 107) on the inner flank and the Piatra Arşiței Massif (samples 66 to 77) on the outer flank. In this last outcrop we sampled the eastern slope of the Piatra Arşiţei Massif, at the confluence between the Lipchieş brook and Bicaz River.

On the Calu brook outcrop the stratified dolomites occur over the stratified limestones. In the section of the Piatra Arşiței Massif they occur directly over the Induan detritic deposits and are followed by the Anisian massive dolomites (Fig. 5). The Olenekian dolomites developed in decimeter- size beds differentiate well from the massive superjacent Early Anisian dolomites.

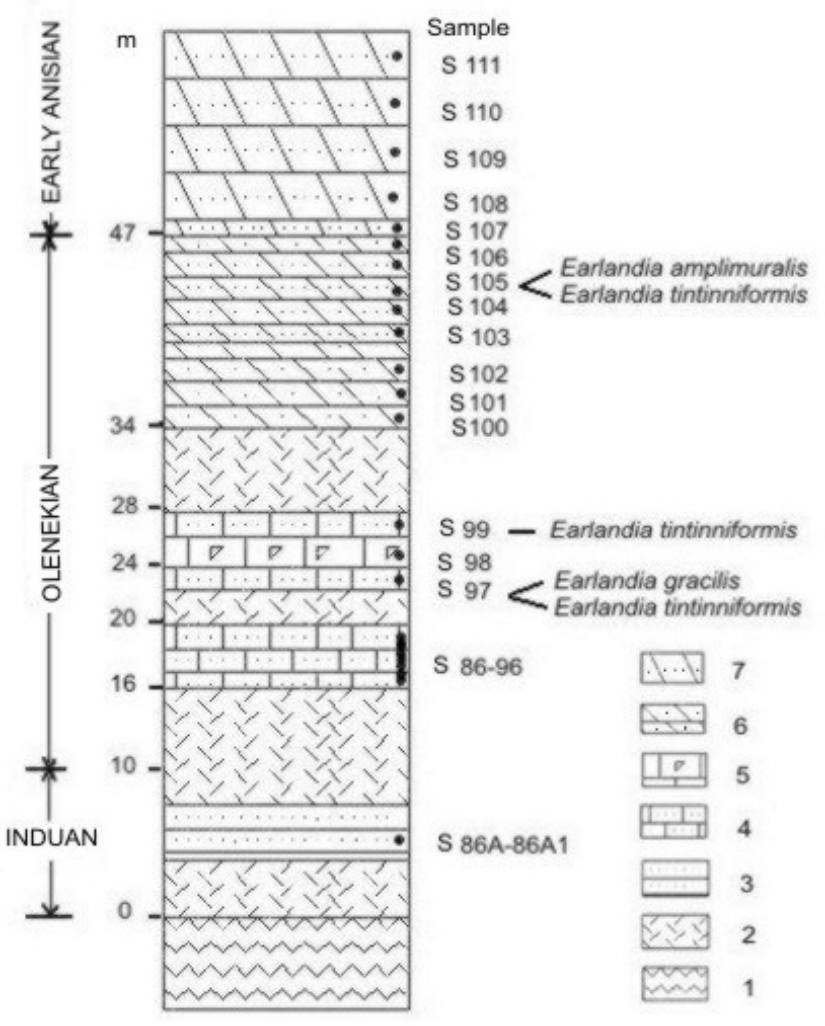

Fig. 5. Biostratigraphical column of the Early Triassic deposits from the Calu outcrop: 1-crystalline basement; 2-deluvial deposits; 3-sandstones; 4-micrites, biomicrites; 5-intramicrites; 6-dolomicrosparites; 7-dolomicrites

The stratified dolomites are heavily fissured. They are generally fine, rarely having a coarse or sometimes microbreccia aspect. They also have different colors, with dominance of grey and white-yellowish shades. On the Calu brook varieties of reddish yellow-spotted or yellowish pinkspotted dolomites also occur. The black coarse dolomites occur also in the Piatra Arşiței Massif. The malachite dolomites (sample 72) with the fine grey pink spotted dolomite intercalations $(8 \mathrm{~cm}$ in thickness) are rare.

\section{FACIES DIFFERENTIATION}

The high microbioclastic diversity and the presence of different allochemes allowed the distinction of several carbonate microfacies. The limestone microfacies have much richer bioclastic content than the dolomite microfacies. We identified 3 limestone and 5 dolomite microfacies types. The identification of carbonate microfacies is made after the system of classification suggested by Folk (1962). This system is based upon the fact that, in principle, carbonate rocks are comparable to sandstones and shales, in regard to sedimentation.

\section{Limestone microfacies (MF-L)}

Among limestone microfacies the micritic varieties are predominant. The grey limestones are made up of micrites with rare bioclasts and biomicrites; rare biointramicrites also occur (Fig. 6, 7).

The micrites (MF-L1) (samples 86, 87, 89, 91, 93, 96, 97, 99) have cryptocrystalline sometimes isotopic calcite cement. They contain many joints of variable thickness. In 

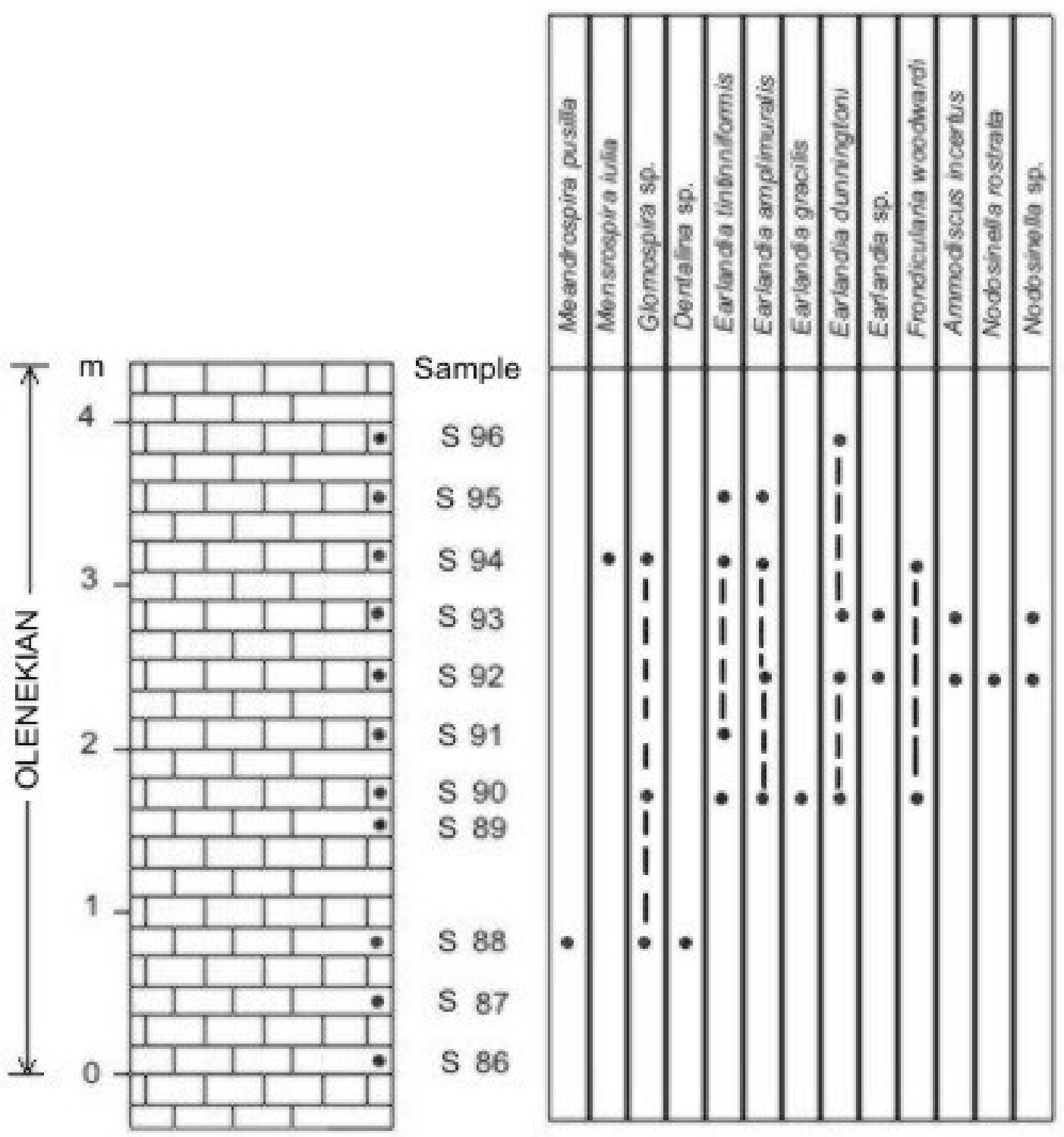

Fig. 6. Detailed biostratigraphical column of the Olenekian biomicrites (the first level of $4 \mathrm{~m}$ ) from the Calu outcrop.

certain thin sections, very fine joints are filled with microsparitic calcite (sample 99). Wide joints are also present in which calcite and dolomite inequigranular xenomorph crystals occur. The sparry crystals are frequently twinned and have micritic edges, and they are arranged across and sometimes even perpendicular on the inner margins of the joints. The micritic edges make difficult the distinction between the wide crystals on the joints and the micritic rock background. Stylolites with a network arrangement occur in few thin sections. The isotropic feature is emphasized in certain cases (sample 86) by the presence of organic material, probably of microbial origin. The bioclastic material is extremely poor being represented by rare ostracods, filaments and calcified radiolarians. Among the foraminifera a few badly preserved specimens of Lagenidae are present. The only determined foraminifera appear as longitudinal and transversal sections and belong to the species Earlandia tintiniformis MISIK, Earlandia gracilis PANTIĆ and Earlandia dunningtoni ELLIOTT.

The biomicrites (MF-L2) are more frequent than the micrites with Earlandia. Some biomicrites have stylolites (Pl. I, Fig. 1) (samples 88, 92), other are fenestrated (samples 94, 95 A). Algal-microbial peloids are relatively frequent. Microsparitic clasts, echinoderm plates, radiolarians, brachiopod fragments and ostracods also occur.
In some thin sections (samples 95, 90), few small gastropods casts with geopetal filling are present (Pl. I, Fig. 2).

Oomodic porosity is present in sample 95, the primary pores being cemented with spary calcite. Together with the mentioned bioclasts few intensely diagenized foraminifera also occur: Nodosariids (Pl. I, Fig. 3), Nodosinella sp. (Pl. I, Fig. 4) and Glomospira sp. (Pl. I, Fig. 5).

The microfauna association determined in biomicrites consists of the following species: Meandrospira pusilla $\mathrm{HO}$ (Pl. I, Fig. 6), Meandrospira iulia PREMOLI SILVA (Pl. I, Fig. 7), Frondicularia woodwardi HOWCHIN, Nodosinella cf. rostrata TRIFONOVA, Ammodiscus incertus D'ORBIGNY, Ammodiscus parapriscus HO, Earlandia gracilis ELLIOTT (Pl. I, Fig. 8), Earlandia amplimuralis PANTIĆ (Pl. II, Fig. 1), Earlandia tintinniformis MISIK, Earlandia dunningtoni ELLIOTT (Pl. II, Fig. 2), Earlandia sp. Among the mentioned taxa Earlandia (longitudinal and transversal sections) is the most frequent.

The biointramicrites (MF-L3) (sample 98) occur rarely towards the upper part of the second stratified limestone pack. Among the allochems the sparitic and microsparitic intraclasts with micritic edges prevail. The rich bioclastic content consists of gastropods, brachiopod fragments, radiolarians, ostracods and numerous echinoderms (especially crinoids) (Pl. II, Fig. 3). 


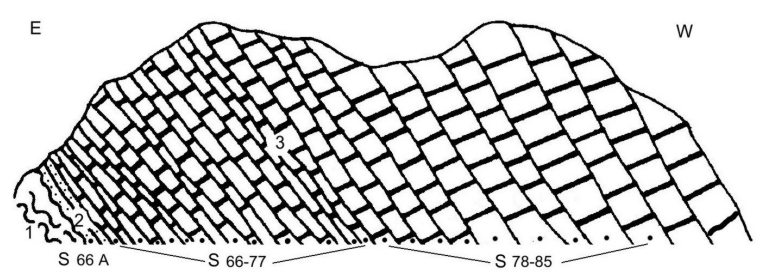

Fig. 7. Geological sketch of the Piatra Arşiței outcrop: 1-crystalline basement; 2-sandstones (Induan); 3-dolomites (Olenekian-Early Anisian); S-sample.

\section{Dolomite microfacies (MF-D)}

The microfacies study was carried out on 20 thin sections. Few microfacies types have been distinguished, which, according to their frequency, are: dolomicrites, dolomicrosparites, dolopelmicrosparites, dolopelmicrites and dolosparites (Fig. 8).

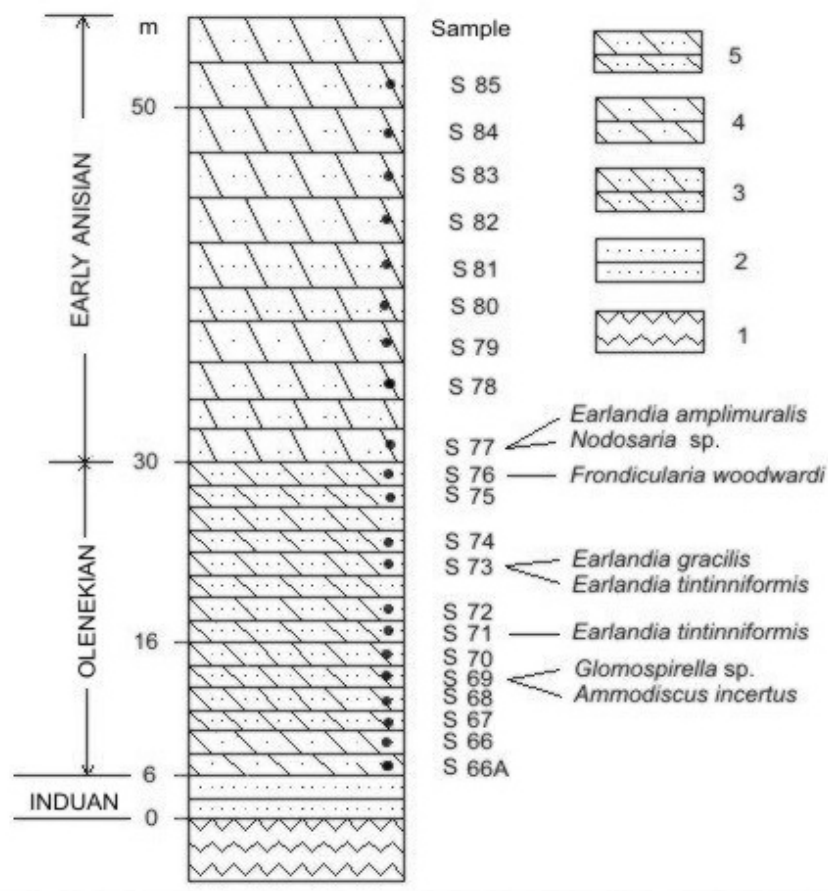

Fig. 8. Biostratigraphical column of the dolomites from the Piatra Arșiței Massif outcrop: 1-crystalline basement;

2-sandstones; 3-dolomicrosparites; 4-dolosparites; 5-dolomicrites

The dolomicrites (MF-D1) present many microsparite areas and rare pellets in the micro-crystalline matrix. Inequigranular calcite crystals and sparry dolomites crystals with subhedral and euhedral shapes are developed on the joints. The large crystals are intensively fissured. The bioclastic content is very poor and even where present (samples 73, 77, 105, 107) it is poorly preserved. The foraminferal assemblage determined in the thin sections is made up of: Earlandia amplimuralis PANTIĆ, Earlandia tinntiniformis MISIK, Earlandia gracilis ELLIOTT and Nodosaria sp. (Pl. II, Fig. 4).

The dolomicrosparites (MF-D2) (samples 67, 70, 71 A$\mathrm{B}, 100,101,102,106)$ are made up of fine microcryptocristalline dolomite and somestime are fenestrate. They also have stylolitic contact between micritic and microsparitic constituents (samples 71 A-B) (Pl. II, Fig. 5). These rocks present arenitic zones with twinned dolomite crystals (Pl. II, Fig. 6) and euhedral to subhedral shapes. Consequently, they have sometimes a microbreccious aspect (planar subhedral fabric) (P1. II, Fig. 7). The bioclasts are extremely rare and are represented by transversal sections of Earlandia with a few specimens belonging to Earlandia tintiniformis MISIK (sample 71). In a single case (sample $100)$ the dolomite is rich in algal-microbial material.

The dolopelmicrosparites (MF-D3) (samples 68, 69) are characterized by a hypidiotropic structure determined by the presence of subhedral and euhedral dolomite crystals in the micro-crystalline matrix. The porosity of these rocks is moderate to weak. The allochemes are represented by pellets with different forms and dimensions and a few bioclasts, from which only Ammodiscus incertus D'ORBIGNY and Glomospirella sp. have been determined.

The dolopelmicrites MF-D4 (sample 76), with fine diaclases, contain a few organic remains, most of them difficult to identify. Besides filaments, the only determined species is Frondicularia woodwardi HOWCHIN. The typical feature of these rocks is the presence of numerous micritic spheroid-ellipsoidal pellets.

The dolosparites MF-D5 (sample 66) generally have a breccious aspect (non planar anhedral fabric) (Pl. II, Fig. 8) due to the presence of the micritic intraclasts. Approximately $30-40 \%$ of the sparry matrix of the rock is represented by the rhombic dolomite crystals of arenitic dimensions. In sample 66 alternations of areas constituted of micritic and pelletal laminas are visible, usually a structure typical of Stromatolite.

\section{MICROPALAEONTOLOGICAL CONTENT}

Microfossils are more abundant in limestones compared to dolomites. The fine carbonate deposits, of micrite, biomicrite and biointramicrite type, are characterized by various bioclasts. The small foraminifera are the only bioclasts that have been determined. Among them, the Moravamminidae are the most frequent in all MF types, represented by several species. In a decreasing frequency order are also present representatives of Fischerinidae, Ammodiscidae, Nodosinnellidae, Nodosariidae and Lagenidae (Table 1). Among these the Fischerinidae species like Meandrospira iulia and Meandrospira pusilla are important for correlation with other areas of the Tethys and for biostratigraphy. Besides foraminifera other bioclasts are also present. In MF-L the most common bioclasts are ostracods and calcitized radiolarians.

The fine pelecypode fragments (filaments) frequently occur in MF-L3 and extremely rare in MF-L1. In MF-L3 and in MF-L2 numerous brachipods fragments and echinoderms, mostly represented by crinoid plates are also abundand. In MF-L2 most of the bioclasts are covered with microbial crusts of cyanobacterial origin.

By way of comparison to MF-L, MF-D presents a very poor bioclastic material that consists of rare filaments covered with microbial crusts and some foraminifera (Table 1). Among these the Moravamminidae species are frequent.

\section{BIOSTRATIGRAPHIC CONSIDERATIONS}

Without palaeontological arguments, the stratified calcareous-dolomitic complex under the Anisian massive dolomites was assigned either to the Permian (Uhlig, 1903; Ilie, 1957) or to the Early Triassic (Paul 1876; Herbich, 1878; Uhlig, 1889; Athanasiu, 1913). 
Table 1. Characteristic smaller foraminifera in the carbonate rocks

\begin{tabular}{|c|c|c|c|}
\hline Foraminifera & Species & Limestones & Dolomites \\
\hline Moravamminidae & $\begin{array}{l}\text { Earlandia tintinniformis ELLIOTT } \\
\text { Earlandia gracilis PANTIĆ } \\
\text { Earlandia dunningtoni ELLIOTT } \\
\text { Earlandia amplimuralis PANTIĆ } \\
\text { Earlandia } \text { sp. }\end{array}$ & $\begin{array}{ll} & - \\
\bullet & - \\
\bullet & - \\
\bullet & -\end{array}$ & $\begin{array}{ll}\cdot \\
\bullet \\
\bullet\end{array}$ \\
\hline Nodosariidae & Frondicularia woodwardi HOWCHIN & $\bullet$ & $\bullet$ \\
\hline Fischerinidae & $\begin{array}{l}\text { Meandrospira iulia PREMOLI SILVA } \\
\text { Meandrospira pusilla } \mathrm{HO}\end{array}$ & $\bullet$ & \\
\hline Nodosinellidae & $\begin{array}{l}\text { Nodosinella } \text { cf. rostrata TRIFONOVA } \\
\text { Nodosinella } \mathrm{sp} .\end{array}$ & $\bullet$ & \\
\hline Ammodiscidae & $\begin{array}{l}\text { Ammodiscus incertus D’ORBIGNY } \\
\text { Ammodiscus parapriscus } \mathrm{HO} \\
\text { Glomospira } \mathrm{sp} . \\
\text { Glomospirella } \mathrm{sp} .\end{array}$ & $\begin{array}{ll}- \\
\bullet \\
\bullet\end{array}$ & $\bullet$ \\
\hline
\end{tabular}

The first geologist that discovered a fauna association in the stratified limestones from the Azodu Mare Peak was Atanasiu (1928). The association consists in the next species: Myphoria (Costatoria) costata ZENK., Myophoria laevigata ZIET., Anophora (Homomya) fassaenis WISSM., Entolium (Pecten) discites SCHLOTH., Entolium discites SCHLOTH. var microtis BITTN., Gervilleia modiola FRENCH., Gervilleia exporrecta LESP., Pseudomontis sp., Natiria (Naticella) cf. costata MÜNST. Starting from this assemblage the author considered the stratified limestones as Campilian (= Olenekian).

In the Hăghimaş Syncline, the same fossiliferous deposits with impressions of Myophoria costata ZENK., and Anoplophora (Homomya) fassaensis WISSM., was identified later at the Trotuş springs (Băncilă, 1941) and in Piatra Ciofronca Massif (Preda \& Pelin, 1963). Turculeț (1967) describes from the same area an assemblage with Myophoria costata ZENK., Anoplophora fassaensis WISSM., Anoplophora fassaensis WISSM. var. brevis FRENCH., Anoplophora canalensis CAT., Entolium discites SCHLOTH., Gervilleia cf. mytiloides SCHLOTH., Pseudomonotis aff. laczkoi BITTN. This fauna confirms the age established by Atanasiu (1928).

A similar association with Myophoria costata ZENK., Natiria costata MÜNST., Entolium discites SCHLOTH., Gervilleia sp. was determined by Grasu (1971) from the stratified limestone-dolomite complex at the confluence between the Calu brook with Piatra Roşie brook.

The microfacies study of the stratified dolomites under the Anisian massives dolomites from the Chicera Massif (Tulgheş Mountain) (Dragastan \& Grădinaru, 1975) proved the existence of a typical Campilian (=Olenekian) association with Glomospira simplex $\mathrm{HO}$ and Earlandia dunningtoni ELLIOTT.

The same authors determined from the stratified greyyellowish biopelsparites of Piatra Pânțăreni Massif (Bicaz Gorge, the eastern flank of the Hăghimaş Syncline), an association with Glomospira simplex HO, Glomospirella shengi HO, Glomospirella irregularis MOELLER and Earlandia dunningtoni ELLIOTT. This association indicates Campilian (= Olenekian)-Early Anisian age. A Campilian (=Olenekian) assemblage was also found in the stratified limestones on the Calu brook (Grasu et al., 1995) with Meandrospira pusilla HO, Earlandia dunningtoni ELLIOTT, Earlandia cf. gracilis PANTIĆ, Nodosaria sp.and Frondicularia sp.

The analysis we made on the samples from the stratified limestones and stratified dolomites provided a rich microfauna association made up of foraminifera species: Meandrospira pusilla $\mathrm{HO}$, Meandrospira iulia PREMOLI SILVA, Frondicularia woodwardi HOWCHIN, Ammodiscus parapriscus HO, Ammodiscus incertus D'ORBIGNY, Nodosinella cf. rostrata TRIFONOVA, Nodosinella sp., Earlandia tintiniformis MISIK, Earlandia dunningtoni ELLIOTT, Earlandia gracilis PANTIĆ, Earlandia amplimuralis PANTIĆ, ? Dentalina sp., Nodosaria sp., Glomospirella sp., Glomospira sp. According to this assemblage we consider the carbonate deposits underlying the Anisian massive dolomites of Olenekian age.

\section{CORRELATION WITH OTHER OLENEKIAN CARBONATE DEPOSITS OF THE TETHYS}

Similar microfauna assemblages were quoted in geological literature by many authors from the carbonate deposits of Romania, as well as from other parts of Europe. In Romania similar assemblages were described for the Campilian (= Olenekian) limestones of Apuseni Mountains and Southern Carpathians.

The carbonate rocks underlying the Guttenstein limestones from North Apuseni Mountains (Codru Nappes) have provided a foraminiferal assemblage of Campilian (=Olenekian) age. The assemblage is typical for the Meandrospira pusilla biozone (Dragastan et al., 1982).

A similar assemblage was described from Campilian (=Olenekian)-Early Anisian deposits of Sasca zone (Dealul Redut member) ( Bucur et al., 1994; Bucur, 1997).

Pantić (1973-1974) has described an assemblage with Meandrospira iulia PREMOLI SILVA, Fronticularia woodwardi HOWCHIN and Glomospira sinensis HO, identified in Stereočka Mountains and Rugovska Klisura from the Outer Dinarides.

In Balkans, the oldest alpine Triassic deposits have been assigned also to the Campilian (= Olenekian) based on foraminaferal assemblage with Meandrospira iulia PREMOLI SILVA, Meandrospira cf. irregularis SALAJ and Ammodiscus incertus D'ORBIGNY. In this region Meandrospira iulia continues its evolution also at the Early Anisian (Urosević, 1971).

The foraminiferal assemblage of the Meandrospira pusilla zone was also found in the Norther Calcareous Alps, Slovak Karst, the norther part of Inner Dinarides, Hungary and Turkey (Zaninetti, 1968; Herak et al., 1967;. BercziMakk, 1976; Zaninetti \& Dager, 1978). 


\section{CONCLUSIONS}

The foraminiferal assemblage identified in the stratified limestones and the stratified dolomites of the Bucovinian Nappe certifies the presence of the Olenekian (= Campilian), the Olenekian age of these deposits being already considered on the base on macrofauna.

The same micropaleontological assemblage was quoted from similar deposits in Romania and other areas of the Tethys (Dragastan et al., 1982; Salaj, 1969; Salaj et al., 1983; Salaj et al., 1988; Budurov \&Trifonova, 1994).

Acknowledgments. Authors would particularly like to thank Prof. Dr. Ioan Bucur from "Babeş-Bolyai" University in Cluj-Napoca and Prof. Dr. Eugen Grădinaru from University of Bucharest for reading the whole manuscript and for making many useful comments on the text and the pictures.

\section{R E F E R E N C E S}

Atanasiu, I. 1928, Étude géologique dans les environs des Tulgheş (Distr. de Neamtz). An. Inst. Geol. Rom., XII: 33-51.

Athanasiu, I. 1913, Cercetări geologice în bazinul Moldovei din Bucovina. Rap. activ. Inst. Geol. Rom., pe anii 19081909, Bucureşti.

Băncilă, I. 1941, Étude géologique dans les Monts Hăghimaş-Ciuc. An. Inst. Geol. Rom., XXI: 42.

Balintoni, I., Gheucă, I. \& Vodă, A. 1983, Alpine and hercynian overthrust nappes from central and southern areas of the east Carpathians Crystallin-Mesozoic Zone. An. Inst. Geol. Rom., LX: 15-22.

Berczi-Makk, A. 1976, Biostratigraphic significance of the Meandrospira pusilla Ho Foraminifera and its distribution in Triassic sedimentary rocks in Hungary, as revealed by hydrocarbon exploring. Acta Geol. Acad. Sci. Hung., 20 (1-2): 101-124.

Bucur, I.I. 1997, Formațiunile mezozoice din zona ReşițaMoldova Nouă (Munții Aninei şi estul Munţilor Locvei). Ed. Presa Universitară Clujeană, Cluj Napoca, 214 pp.

Bucur, I.I., Strutinski C. \& Pop-Strătilă D. 1994, Middle Triassic deposits and calcareous algae from the Sasca zone (Southern Carpathians, Romania). Facies, 30: 85-100.

Budurov, K. \& Trifonova, E. 1994, Progress in concepts about conodont and foraminifera zonal standards of the Triassic in Bulgaria. Mém. Géol., 22: 9-13.

Dimian, M., 1970, Studii stratigrafice şi tectonice în regiunea Lucina-Moldova Sulița-Breaza, Carpații Orientali. D. S. Inst. Geol. Geofiz., LV/5, 1967-1968: $152-175$

Dragastan, O., \& Grădinaru, E. 1975, Asupra unor alge, foraminifere, sphinctozoare şi microproblematice din Triasicul din Carpaţii Orientali şi Dobrogea de Nord. St. cerc. geol. geofiz. geogr., Geol., 20 (2): 247-254.

Dragastan, O. 1980, Alge calcaroase din Mezozoicul şi Terțiarul României. Ed. Acad., Bucureşti, 169 pp.

Dragastan, O., Diaconu, M., Popa, E. \& Damian, R. 1982, Biostratigraphy of the Triassic Formations in the East of the Pădurea Craiului Mountains. D. S. Inst. Geol. Geofiz., LXVII/4, 1979-1980: 29-61.

Folk R.L. 1962, Spectral subdivision of limestones types. In W.E. Ham (Ed), Classification of Carbonate Roks. Am. Assoc. Petrol. Geol. Mem. 1: 62-84.
Grasu, C. 1971, Récherches géologiques dans le sédimentaire mesozoïque du bassin supérieur de Bicaz. Lucr. Staț. "Stejarul”, geol-geogr., IV, 55 pp.

Grasu, C., Catana, C., Turculeț, I. \& Niţă, M. 1995, Petrografia mezozoicului din "Sinclinalul marginal extern”. Ed. Acad. Române, Bucureşti, 192 pp.

Herak, M., Sokać, B. \& Šcávničar, B. 1967, Correlation of the Triassic in SW Lika, Paklenica and Gorski Kotar Croatia. Geol. Carpathica, XVIII (2): 189-202.

Herbich, F. 1878, Das Szeklerland, Mitt. Jahr. ung. geol. Aust., Bd. V, Budapest.

Ilie, M. 1957, Cercetări geologice în regiunea RarăuCâmpulungul Moldovei-Pârâul Cailor. An. Com. Geol. Rom., XXIV: 107-219.

Mureşan, M. 1967, Structura tectonică a părții de sud a zonei cristalino-mezozoice din Carpații Orientali. Stud. Cercet. Geol. Geofiz. Geogr., Geol., 12 (1): 243-247.

Mureşan, M. 1976, O nouă ipoteză privind pânzele bucovinice din partea sudică a zonei cristalino-mezozoice a Carpaților Orientali. D. S. Inst. Geol. Geofiz, vol. LXII (5): 77-94.

Mutihac, V. 1968, Structura geologică a sinclinalului marginal extern. Ed. Acad. Române, Bucureşti, 104 pp.

Mutihac, V. 1969, Structura geologică a sinclinalului marginal extern la nord de Valea Moldovei Rarău. D. S. Inst. Geol. Geofiz., LIV (3), 1966-1967: 213-225.

Mutihac, V. 1990, Structura geologică a teritoriului României. Ed. Tehnică, Bucureşti, 423 pp.

Nedelcu, L. 1982, Unitatea tectonică de Chiril - o nouă unitate bucovinică a Carpaților Orientali în regiunea dintre Muntele Giumalău şi valea Puzdra. Stud. Cercet. Geol. Geofiz. Geogr., 27: 69-81.

Pantić ,S. 1973-1974, Contributions to the Stratigraphy of the Triassic of the Frokletije Mountains. Vesnik Geologija, 31-32 (A): 135-167.

Patrulius, D. 1966, Dorsala dolomitică, rudiment al Carpaților Orientali în timpul Triasicului. D. S. Inst. Geol. Geofiz., LII/2 (1964-1965): 135-160.

Patrulius, D. 1967, Le Trias des Carpates Orientales de Roumanie. Geologicky Sbornik. XVIII (2): 233-244.

Paul, K. 1876, Grundzüge der Geologie der Bukowina. Jarhrb. d. k. k. geol., R-A., Wien.

Preda, I. \& Pelin, M. 1963, Contribuții la cunoaşterea geologiei împrejurimilor Lacului Roşu. Soc. de Şt. Nat. Geogr., Comunicări de Geol., II (1960-1961): 16-25.

Salaj, J. 1969, Essais de zonations dans le Trias des Carpathes Occidentales d'après les foraminifères. Geologické práce. 48: 123-128.

Salaj, J., Borza, K. \& Samuel, O. 1983, Triassic Foraminifera of the West Carpathians. Geologický Ústav Dionyza Štúra, Bratislava, 215 pp.

Salaj, J., Trifonova, E. \& Gheorghian, D. 1988, A Biostratigraphic Zonation based on benthic Foraminifera in the Triassic deposits of the Carpatho-Balkans. Rev. Paleobiol., vol spec. 2., Benthos '86: 153-159.

Săndulescu, M. 1968, Probleme tectonice ale sinclinalului Hăghimaş. D. S. Inst. Geol. Geofiz, vol. LIII (3) (19651966): 221-240.

Săndulescu, M. 1969, Structura geologică a părții centrale a sinclinalului Hăghimaş. D. S. Inst. Geol. Geofiz, LIV (3) (1966-1967), Bucureşti, 228-250.

Săndulescu, M. 1973, Contribuții la cunoaşterea structurii geologice a sinclinalului Rarău, sectorul central. D. S. Inst. Geol., LIX (5): 59-85. 
Săndulescu, M. 1975, Studiul geologic al părții centrale şi nordice a sinclinalului Hăghimaş (Carpaţii Orientali). An. Inst. Geol. Geofiz., XLV: 1-160.

Săndulescu, M., Mureşan, M. \& Mureşan, G. 1975, Geological map, Dămuc paper, scale 1:50 000, Inst. Geol. Geofiz., Bucureşti.

Săndulescu, M. 1984, Geotectonica Românei. Ed. Tehnică, Bucureşti, 336 pp.

Sudar, M. 1986, Triassic microfossils and biostratigraphy of the Inner Dinarides between Gučevo and Ljubisnja Mts. Jugoslavia. Ann. Géol. de la Pén.Balk., 50: 151-382.

Turculeț, I. 1967, Considerații stratigrafice şi paleontologice asupra calcarelor de Hallstatt din Dealul Cailor (RarăuBucovina). Anal. Univ. Iaşi, geol. XIII/IIb: 73-81.

Uhlig, V. 1889, Vorläufiger Bericht ueber eine geologische Reise in das Gebiet der goldenen Bistritz (noröstliche Karpathen). Sitz. Akad. Wiss, 98/1, Wien.
Uhlig, V. 1903, Bau und Biled der Karpathen. Wien.

Uhlig, V. 1907, Ueber Tektonik der Karpaten. Sitz. Akad. Wiss. natur, 116, Wien.

Urosević, D. 1971, A survey of triassic fauna and flora of Stara Planina Mt. (Carpatho-Balkan Region). Ann. geol. de la Pen. Balk., 36: 252-292.

Vodă, A. 1980, Bordura estică a zonei cristalino-mezozoice dintre Broşteni şi Bicaz (Carpații Orientali). D. S. Inst. Geol. Geofiz, LXV/5 (1977-1978): 181-192.

Zanninetti, L. 1968, Les foraminifères du Trias de la région de l’Almtal (Zalzkammergut Haute-Autriche), Genève Edition Médecine et Hygiène (abstract of $\mathrm{PhD}$ Thesis).

Zanninetti, L. \& Dåger, Z. 1978, Biostratigraphie intégré et paléoécologie du Trias de la péninsule de Kocaeli Turquie. Eclogae geol. Helv., 71 (1): 85-104. 
PLATE I

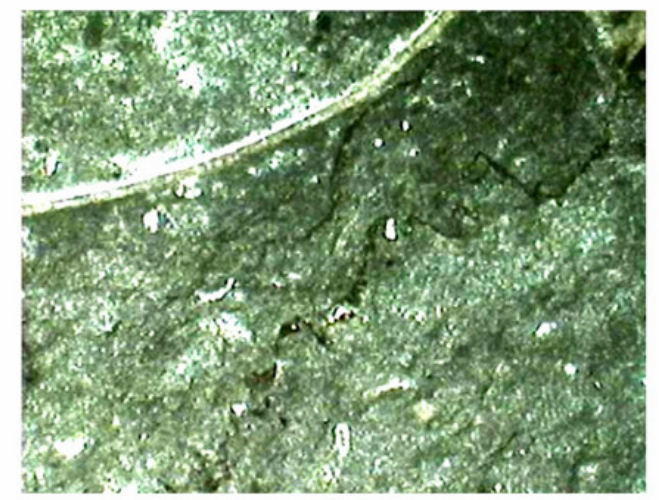

1

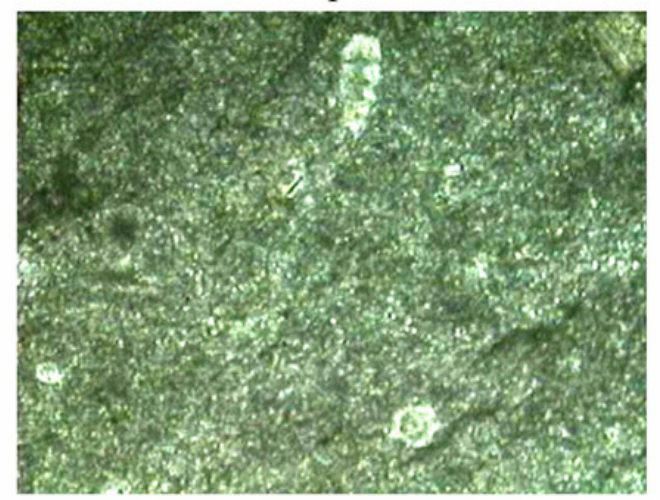

3

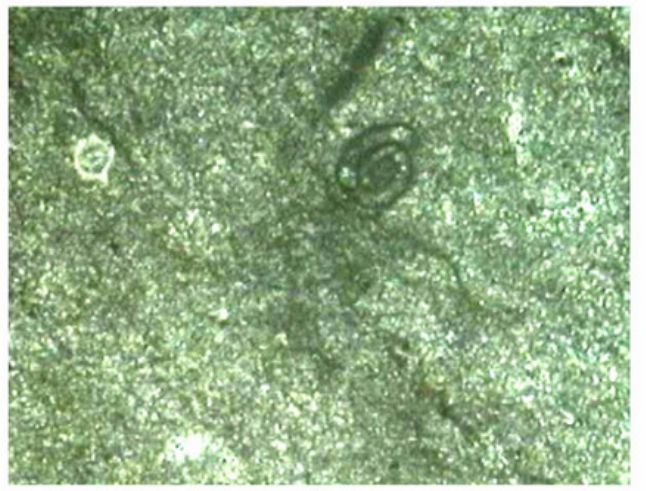

5

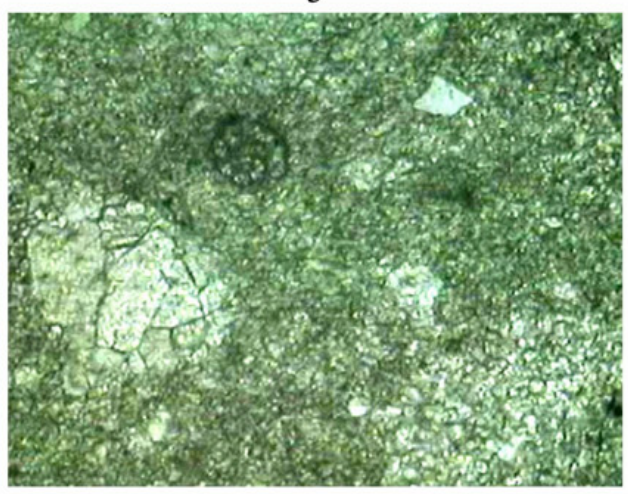

7

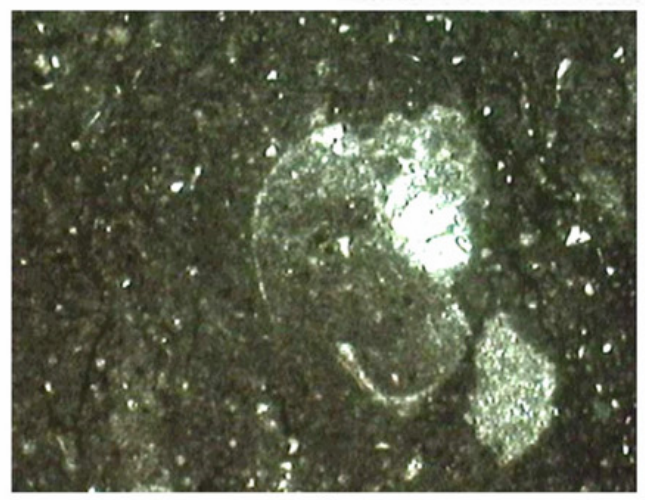

2

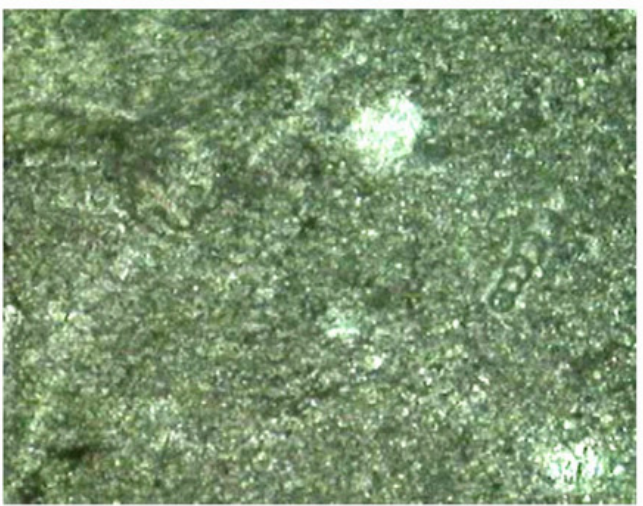

4

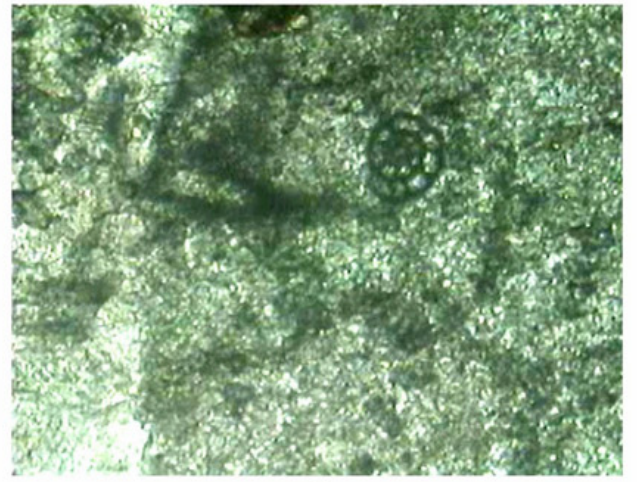

6

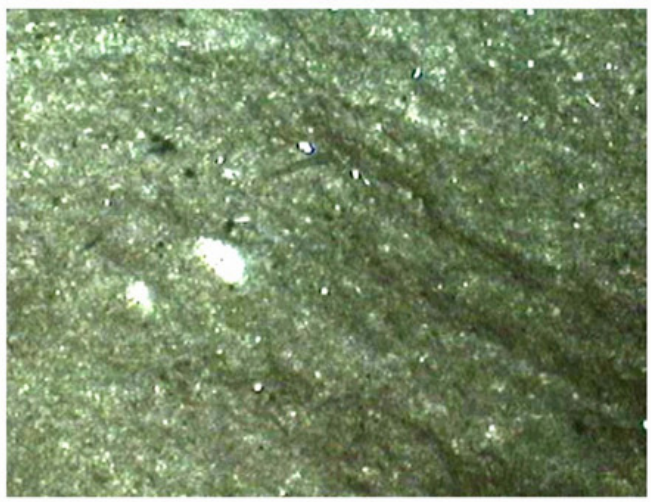

8

Plate I

Fig. 1. Biomicrite with bivalve shells and high columnar stylolites. Sample 88b, X24.

Fig. 2. Longitudinal section through a gastropod cast. The shell cast has a geopetal infil. Sample 95, X24.

Fig. 3. Biomicrite with Nodosariid foraminifera. Sample 88a, X24.

Fig. 4. Biomicrite with Nodosinella sp. Sample 92g, X70.

Fig. 5. Biomicrite with Glomospira sp. Sample 88, X24.

Fig. 6. Biomicrite with Meandrospira pusilla HO. Sample 88c, X24.

Fig. 7. Biomicrite with Meandrospira iulia PREMOLI SILVA. Sample 94k, X24.

Fig. 8. Biomicrite with Earlandia gracilis ELLIOTT. Sample 97a, X24.

Fig. 1 - 8. Calu brook outcrop. 
PLATE II

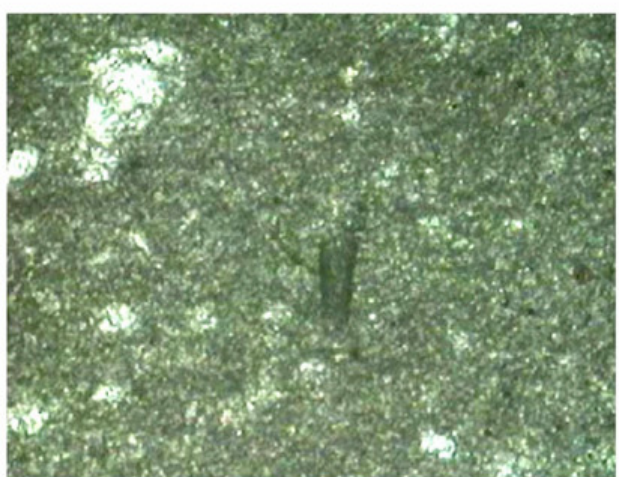

1

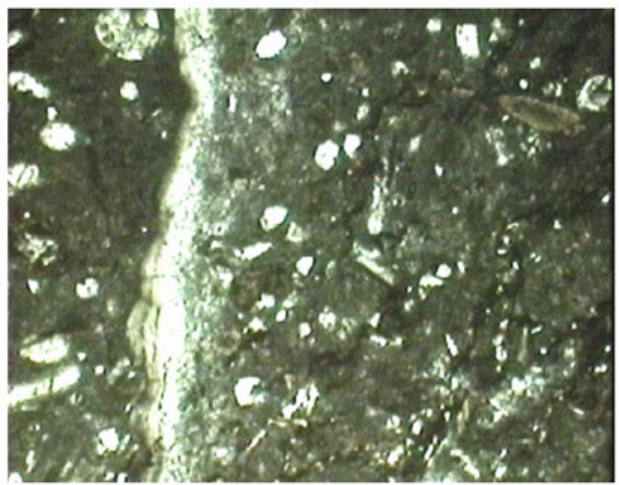

3
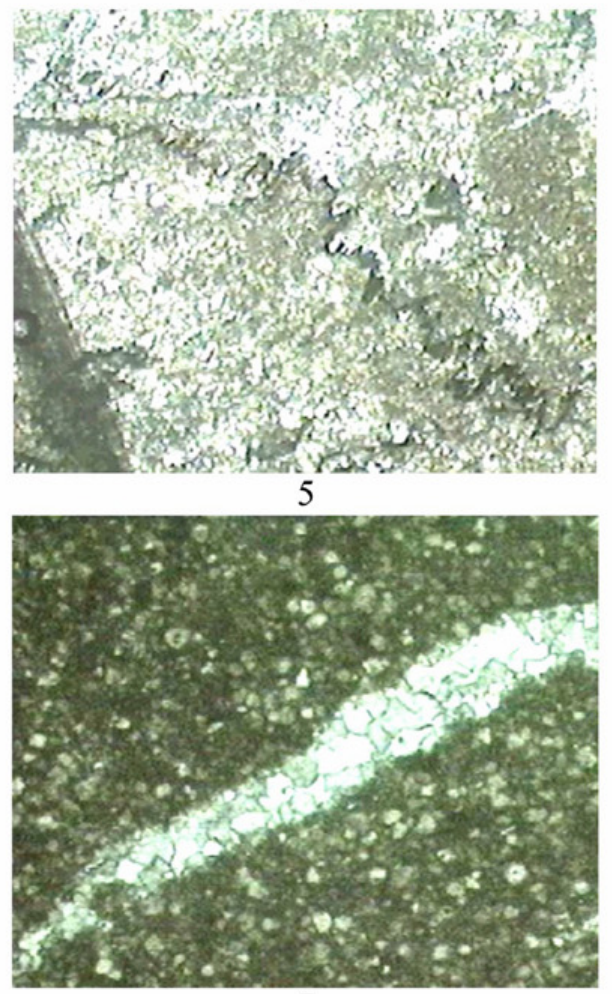

7

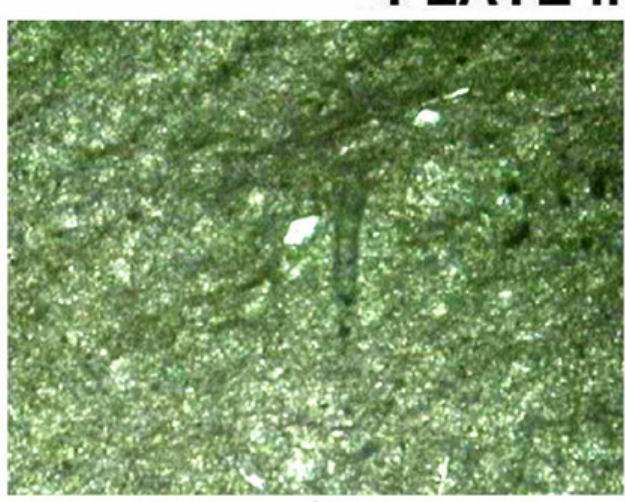

2

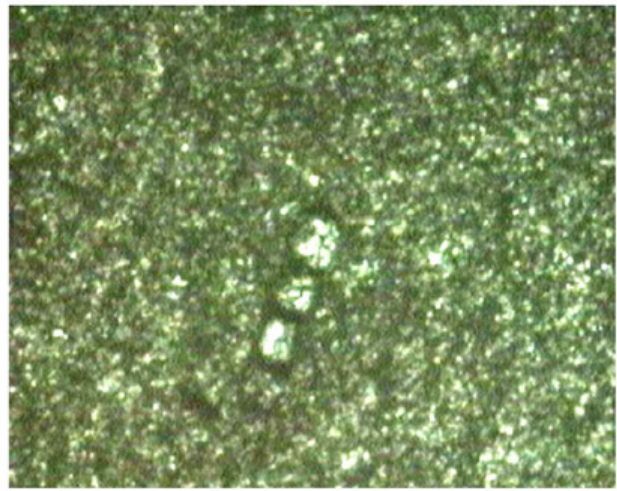

4

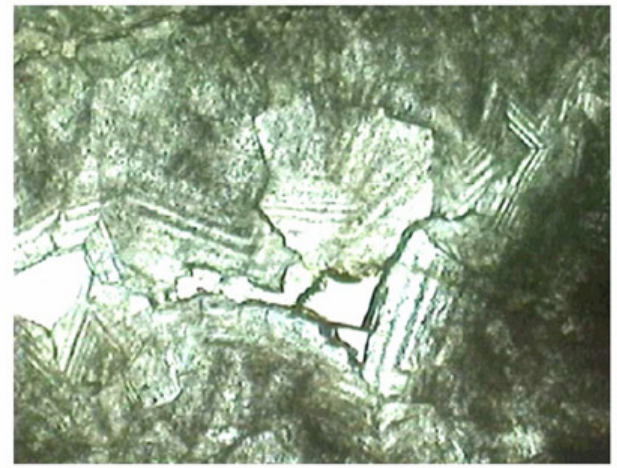

6

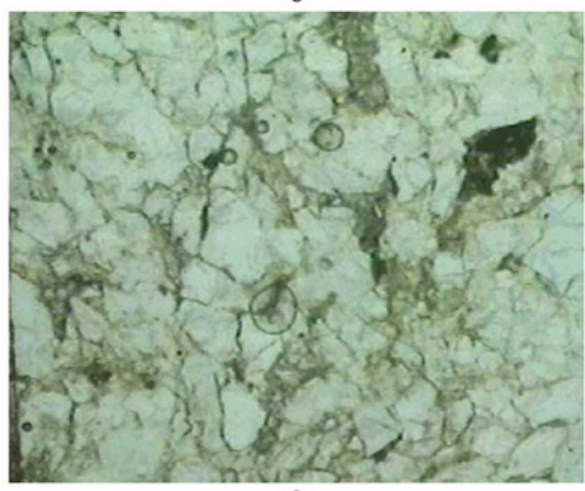

8

Plate II

Fig. 1. Biomicrite with Earlandia amplimuralis PANTIĆ. Sample 94i, X70.

Fig. 2. Biomicrite with Earlandia dunningtoni ELLIOTT. Sample 97b; X70.

Fig. 3. Biointramicrite with ostracods and crinoid plates. Sample 98c, X24.

Fig. 4. Dolomicrite with Nodosaria sp. Sample 107a, X24.

Fig. 5. Dolomicrite with low amplitude peaked stylolites Sample 71AB, X24.

Fig. 6. Dolomite banded crystals formed through calcite substitution (diagenetic metasomatism process). Sample 101, X24.

Fig. 7. Dolomicrosparite with a planar subhedral fabric. Sample 67, X24.

Fig. 8. Dolosparite with a nonplanar anhedral fabric. Sample 66a, X24.

Fig. 1 - 4, 6. Calu brook outcrop; 